\title{
Measurement of The Green Waste IndexStudy in Bandung City
}

\author{
Indrawati ${ }^{1}$, Fariz Indra Permana ${ }^{2}$ \\ ${ }^{1}$ Telkom University, Bandung, Indonesia \\ 2 Telkom University, Bandung, Indonesia \\ Email: indrawati@telkomuniversity.ac.id; farizindrapermana@telkomuniversity.ac.id
}

\section{ARTICLE INFO \\ Date Received: 04 \\ November 2020 \\ Revision Date : 29 \\ November 2020 \\ Date Received : 02 \\ January 2021}

\section{Keywords:}

Green City;

Green Waste;

Reduce;

Reuse;

Recycle; \begin{abstract}
The rise of population is one of the factors on the increasing amount of waste in urban area. Aside from the mentioned factor, the increase of waste also caused by changes in society consumption pattern which significantly affect the waste amount, especially in urban areas. The changes in consumption pattern shown from daily lives of urban residents, for example the habit in fast food consumption which generates garbage in the form of food container, disposable spoon and forks, and wrappers. In the City of Bandung area, to increase the effectivity in waste management, the government strengthen the waste management regulation, from home to industrial scale. Managing waste from its source is a strategic point in supporting the success of waste management. This research aims to determine Bandung green waste index, in which green waste index in a waste management concept using 3R (Reduce, Reuse, Recycle), which also an attribute of green city. This research was performed by conducting interviews to 30 respondents, screened using the quadruple helix concept: government, expert/researcher, business actors, and general society. Based on the method, this research is categorized as a mixedmethod study whereupon the researcher employed both qualitative and quantitative methods. Triangulation, peer debriefing, and word association were the qualitative methods employed while validity and reliability, spearman rank, and index tabulation were the quantitative methods used.The results of the research indicate that the green waste index of city of Bandung was 72.44 , which falls in the category "adequate." The results illustrate that although the green waste management is acceptable, several aspects were still lacking. This refers to the grading scale utilized by assessors of the Indonesian Ministry of Research and Technology/National Research and Innovation (RISTEKDIKTI).
\end{abstract}

\section{Coresponden Author:}

Email: indrawati@telkomuniversity.ac.id Article with open access under license

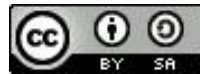

Cleanliness Deni Nurdyana Hadimin said, the production of waste produced by the citizens of Bandung reached 1600 tons per day. Where around 100 - 150 tons are plastic waste (tribunnews, 2018). In 2015, the City of Bandung was incorporated in an international green city organization under the Organization for Economic Cooperation and Development (OECD) (tribunnews, 2015). Green city is a concept of sustainable and environmentally friendly development achieved with a balanced development strategy between economic growth, social life, and environmental protection so that cities become habitable places not only for the current generation, but also the next generation. One element of a green city is green waste, where green waste management is based on the principle of reduce, reuse, and recycle.

In addition, green waste management must also be supported by environmentally friendly waste treatment and disposal technology (Bapeda aceh, 2019). 
Bandung City Government implements green waste that contains the determination of waste reduction targets, strategies to improve the quality and reach of cleaning services, provision of facilities and infrastructure, the role of the community, partnerships, the use of green technology and the development of waste treatment infrastructure. The basic principle of green waste is the state of free of waste through $3 R$ namely Reduce, Reuse, Recycle (BKPRN, 2012).

Based on the literature study conducted, there are indicators used as parameters for measuring green waste. In this study, researchers will test the indicators produced and calculate the green waste concept index in the city of Bandung. The researcher wants to see what variables and indicators can be used to measure green waste in Bandung, know the measurement model used to measure green waste in Bandung, and find out the amount of green waste index in Bandung.

\section{LITERATURE REVIEW}

\section{Green Marketing}

Today businesses and consumers have begun to challenge the environmentally friendly products because both businesses and consumers are becoming more concerned about the environment, health, and wealth to protect the earth's resources and the environment (Nagaraju \& Thejaswini, 2014). The American Marketing Association (AMA) defines green marketing as marketing of a product that is believed to be environmentally friendly, where the company carries out various activities such as product adjustment, modification of production processes, packaging, labeling, marketing strategies (Yazdanifard \& Mercy, 2011). The main concern of business today must be placed on the key to environmental preservation rather than increasing business profitability (Boztepe, 2012).

\section{Green City}

Green city is an environmentally friendly city by utilizing water and energy resources effectively and efficiently, reducing waste, implementing an integrated transportation system, guaranteeing environmental health, synergizing the natural and artificial environment, based on urban planning and design which is in line with the principles of sustainable development. Green city has characteristics with eight attributes including, green planning and design, green open space, green energy, green water, green waste, green building, green transportation, and green community (Kementerian PUPR, 2017).

\section{Green Waste}

Green waste is a method of processing waste that does not use energy that can damage the environment, and prefers prevention of the production of waste and waste from both the household and industrial sectors ("Glob. Waste Manag. Outlook," 2016). It can be concluded that basically the concept of green waste is a concept of waste management by applying the $3 \mathrm{R}$ principle, namely Reduce, Reuse, and Recycle which is applied to the community.

\section{METHOD \\ Research Stages}

The research design is a blueprint plan that will be carried out by researchers related to the formulation of problems, collection, measurement, processing, and data analysis to answer research questions so that the objectives of the study are achieved (Yazdanifard \& Mercy, 2011). In this study, the stages of research used are as follows:

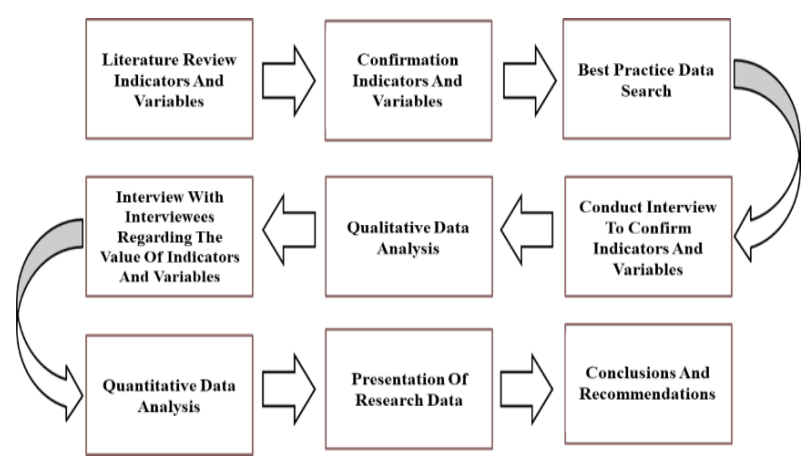

\section{Operational Variables}

Based on a literature study conducted, researchers found there are 5 variables and 22 indicators in measuring green waste as follows:

Table 1

Operational Variables

\begin{tabular}{|c|c|c|}
\hline \\
\hline Dimension & Variables & Indicators \\
\hline \multirow{19}{*}{$\begin{array}{l}\text { Green } \\
\text { Waste }\end{array}$} & \multirow[t]{6}{*}{$\begin{array}{l}\text { Environment } \\
\text { Control }\end{array}$} & $\begin{array}{l}\text { Source separation of 'dry } \\
\text { recyclables' }\end{array}$ \\
\hline & & $\begin{array}{l}\text { Waste captured by the solid } \\
\text { waste management and } \\
\text { recycling system }\end{array}$ \\
\hline & & $\begin{array}{l}\text { Degree of controlled of } \\
\text { treatment and disposal }\end{array}$ \\
\hline & & Waste collection coverage rate \\
\hline & & Waste recycling rate \\
\hline & & $\begin{array}{l}\text { Decreasing the amount of } \\
\text { waste per person }\end{array}$ \\
\hline & \multirow{7}{*}{$\begin{array}{l}\text { Financial } \\
\text { Sustainability }\end{array}$} & Access to capital for investment \\
\hline & & $\begin{array}{l}\text { Local cost recovery - from } \\
\text { business and institutions }\end{array}$ \\
\hline & & Move from linear economy \\
\hline & & waste management to the \\
\hline & & circular economy \\
\hline & & $\begin{array}{l}\text { Local cost recovery - from } \\
\text { households }\end{array}$ \\
\hline & & Unit cost of recycling operation \\
\hline & \multirow[t]{6}{*}{$\begin{array}{l}\text { Operational } \\
\text { Management }\end{array}$} & $\begin{array}{l}\text { Degree of clean technology } \\
\text { used }\end{array}$ \\
\hline & & Suitable infrastructure \\
\hline & & $\begin{array}{l}\text { Develop and keep improving a } \\
\text { waste information system }\end{array}$ \\
\hline & & $\begin{array}{l}\text { Number of disposal sites } \\
\text { complying with defined } \\
\text { operation standards }\end{array}$ \\
\hline & & $\begin{array}{l}\text { Degree of communication and } \\
\text { colaboration for recycling } \\
\text { progremme }\end{array}$ \\
\hline & & Degree of performance \\
\hline
\end{tabular}




\begin{tabular}{lll}
\hline Dimension & \multicolumn{1}{c}{ Variables } & \multicolumn{1}{c}{ Indicators } \\
\cline { 2 - 3 } & & monitoring \\
\cline { 2 - 3 } & Public & \multicolumn{1}{c}{ Effectiveness in achieving } \\
and Awareness & behavior change \\
\cline { 2 - 2 } & & Stakeholder participation \\
\cline { 2 - 2 } & & Public education \& awareness \\
\cline { 2 - 2 } & Institutional & Institutional arrangements \\
\cline { 2 - 2 } & and Policy & Endorsed national waste \\
& Framework & strategies \\
\hline
\end{tabular}

The researcher confirms the variables and indicators based on the literature review that has been done through in-depth interviews with informants. In-depth interviews were conducted on the sample using a quadruple helix approach involving four parties comprising the Government, Businesses, Academics/Researchers, and the Community as many as 30 resource persons.

\section{METHOD}

This research uses a mixed method, which combines qualitative and quantitative research. The mixed method was chosen as a useful strategy for gaining an understanding of the problem formulation more complete such as to explain quantitative results by collecting and analyzing qualitative followup data (Creswell \& Creswell, 2017).

In conducting research qualitatively researchers conducted data analysis techniques with the triangulation method, where triangulation is a combination or combination of various methods used to study interrelated phenomena from different perspectives and perspectives (Indrawati, 2015), peer de briefing used by researchers to explore the results obtained in the form of discussions with the green city research group. In this study researchers conducted discussions with teammates who were considered to know the characteristics of the research subjects, and word association, is the process of collecting pieces of text or pieces of images and writing them into categories, then labeling these categories with special terms that are often based on terms / languages that actually originate from sources.

As for quantitative research, researchers conduct validity and reliability tests to ensure the validity and reliability of research results that have been carried out qualitatively then the research instruments are tested quantitatively (Indrawati, 2015). Statistical measurements are performed using the Spearman rank correlation, Spearman rank correlation is used to measure the level or the closeness between two variables, namely the independent variable and the dependent variable which is ordinal scale, know the level of compatibility of two variables with the same group, get empirical validity of data collection tools, and find out the reliability of data collection tools (dan Sunarto, 2007). In addition, researchers assessed the tabulation index, the value generated from the measurement of a concept linked to data collection in the field. The assessment used in this study is a number that has a range of values based on the assessment of the National Higher Education reviewer assessor (Indrawati, 2015). The agreed evaluation ranges are as follows :

1. A score of $0-60$ is considered very poor and needs a lot of improvement.

2. Figures 61-70 are considered not good, there are still many shortcomings, but still within reasonable limits.

3. Figures 71-80 are considered sufficient, satisfying, some things are still lacking.

4. Figures 81-90 are considered good, satisfying, in line with expectations, and slightly lacking.

5. Figures 91-100 were considered very good, very satisfying, in accordance with the expectations of the participants almost no shortcomings.

\section{RESULT AND DISCUSSION \\ Analysis \\ Qualitative Result}

Based on statements that have been obtained from resource persons, labeling of each variable and indicator is carried out. The results of labeling the variables and indicators are as follows:

Table 2

Qualitative Results

\begin{tabular}{lc}
\hline \multicolumn{1}{c}{ Variable } & Percentage Agree \\
\hline Environment Control & $100 \%$ \\
\hline Financial Sustainability & $100 \%$ \\
\hline Operational Management & $100 \%$ \\
\hline Public Participation and Awareness & $100 \%$ \\
\hline Institutional and Policy Framework & $100 \%$ \\
\hline
\end{tabular}

\begin{tabular}{lc}
\hline \multicolumn{1}{c}{ Indicator } & Percentage Agree \\
\hline Source separation of 'dry recyclables' & $100 \%$ \\
\hline $\begin{array}{l}\text { Waste Captured by the solid waste } \\
\text { management and recycling system }\end{array}$ & $100 \%$ \\
\hline $\begin{array}{l}\text { Degree of controlled of treatment and } \\
\text { disposal }\end{array}$ & $100 \%$ \\
\hline Waste Collection Coverage rate & $100 \%$ \\
\hline Waste Recycling rate & $94 \%$ \\
\hline $\begin{array}{l}\text { Decreasing Number of Garbage Dumps } \\
\text { per Life }\end{array}$ & $100 \%$ \\
\hline Access to capital for investment & $94 \%$ \\
\hline $\begin{array}{l}\text { Local cost recovery - from business and } \\
\text { institutions }\end{array}$ & $94 \%$ \\
\hline $\begin{array}{l}\text { Move from linear economy waste } \\
\text { management to the circular economy }\end{array}$ & $100 \%$ \\
\hline Local cost recovery - from households & $100 \%$ \\
\hline Unit cost of recycling operation & $12 \%$ \\
\hline Degree of clean technology used & $100 \%$ \\
\hline Suitable infrastructure & $100 \%$ \\
\hline $\begin{array}{l}\text { Develop and keep improving a waste } \\
\text { information system }\end{array}$ & $94 \%$ \\
\hline $\begin{array}{l}\text { Number of disposal sites complying with } \\
\text { defined operation standards }\end{array}$ & $100 \%$ \\
\hline $\begin{array}{l}\text { Degree of communication and } \\
\text { colaboration for recycling programme }\end{array}$ & $100 \%$ \\
\hline Degree of performance monitoring & $100 \%$ \\
\hline $\begin{array}{l}\text { Effectiveness in achieving behavior } \\
\text { change }\end{array}$ & $100 \%$ \\
\hline Stakeholder participation & $100 \%$ \\
\hline Public education \& awareness & $100 \%$ \\
\hline Institutional arrangements & \\
\hline Endorsed national waste strategies & $100 \%$ \\
\hline & \\
\hline
\end{tabular}


Based on the results of the confirmation of variables and indicators to resource persons, the indicator of unit cost of recycling operation or recycling operational costs has a small percentage value of the financial sustainability variable which is $12 \%$. So the researcher decide not to use these indicators in subsequent quantitative calculations

\section{Qualitative Result}

Based on the results of quantitative analysis by calculating the Spearman rank correlation and scoring data based on variables and indicators obtained from qualitative results, the following results are obtained:

Table 3

Quantitative Results

\begin{tabular}{|c|c|c|c|c|}
\hline Variable & Correlation & Result & Score & Categori \\
\hline $\begin{array}{l}\text { Environment } \\
\text { Control }\end{array}$ & 0.892 & $\begin{array}{c}\text { Positive } \\
\text { Correlation }\end{array}$ & 69.87 & Not good \\
\hline $\begin{array}{l}\text { Financial } \\
\text { Sustainability }\end{array}$ & 0.851 & $\begin{array}{c}\text { Positive } \\
\text { Correlation }\end{array}$ & 71.38 & Sufficient \\
\hline $\begin{array}{l}\text { Operational } \\
\text { Management }\end{array}$ & 0.928 & $\begin{array}{c}\text { Positive } \\
\text { Correlation }\end{array}$ & 70.53 & Sufficient \\
\hline $\begin{array}{l}\text { Public } \\
\text { Participation } \\
\text { and } \\
\text { Awareness }\end{array}$ & 0.954 & $\begin{array}{l}\text { Positive } \\
\text { Correlation }\end{array}$ & 74.61 & Sufficient \\
\hline $\begin{array}{l}\text { Institutional } \\
\text { and Policy } \\
\text { Framework }\end{array}$ & 0.964 & $\begin{array}{l}\text { Positive } \\
\text { Correlation }\end{array}$ & 75.83 & Sufficient \\
\hline
\end{tabular}

\begin{tabular}{cccc} 
Framework & & & \\
\hline Indicator & Correlati & Result Score Categori
\end{tabular}

\begin{tabular}{lcccc}
\hline \multicolumn{1}{c}{ Indicator } & $\begin{array}{c}\text { Correlati } \\
\text { on }\end{array}$ & Result & Score & Categori \\
\hline $\begin{array}{l}\text { Source } \\
\text { Separation of } \\
\text { Dry Recyclables }\end{array}$ & 0.750 & $\begin{array}{c}\text { Positive } \\
\text { Correlatio } \\
\mathrm{n}\end{array}$ & 65.90 & Not good \\
\hline
\end{tabular}

\begin{tabular}{|c|c|c|c|c|}
\hline \\
\hline $\begin{array}{l}\text { Waste Captured } \\
\text { by The Solid } \\
\text { Waste }\end{array}$ & 0.773 & $\begin{array}{l}\text { Positive } \\
\text { Correlatio }\end{array}$ & 69.50 & Not good \\
\hline $\begin{array}{l}\text { Management } \\
\text { and Recycling }\end{array}$ & 0.173 & $n$ & 09.00 & INol good \\
\hline
\end{tabular}

and Recycling

System

\begin{tabular}{|c|c|c|c|c|}
\hline $\begin{array}{l}\text { Degree of } \\
\text { Controlled of } \\
\text { Treatment and } \\
\text { Disnosal }\end{array}$ & 0.799 & $\begin{array}{c}\text { Positive } \\
\text { Correlatio } \\
n\end{array}$ & 70.90 & Not good \\
\hline
\end{tabular}

Disposal

\begin{tabular}{|c|c|c|c|c|}
\hline $\begin{array}{l}\text { Waste } \\
\text { Collection } \\
\text { Coverage Rate }\end{array}$ & 0.745 & $\begin{array}{c}\text { Positive } \\
\text { Correlatio } \\
n\end{array}$ & 70.40 & Not good \\
\hline $\begin{array}{l}\text { Waste Recycling } \\
\text { Rate }\end{array}$ & 0.639 & $\begin{array}{c}\text { Positive } \\
\text { Correlatio } \\
n\end{array}$ & 71.72 & Sufficient \\
\hline $\begin{array}{l}\text { Decreasing } \\
\text { Number of } \\
\text { Garbage Dumps } \\
\text { per Life }\end{array}$ & 0.661 & $\begin{array}{c}\text { Positive } \\
\text { Correlatio } \\
n\end{array}$ & 70.78 & Not good \\
\hline $\begin{array}{l}\text { Access to } \\
\text { Capital for } \\
\text { Investment }\end{array}$ & 0.784 & $\begin{array}{c}\text { Positive } \\
\text { Correlatio } \\
n\end{array}$ & 69.20 & Not good \\
\hline $\begin{array}{l}\text { Local Cost } \\
\text { Recovery - } \\
\text { From } \\
\text { Businesses and } \\
\text { Institutions }\end{array}$ & 0.736 & $\begin{array}{c}\text { Positive } \\
\text { Correlatio } \\
n\end{array}$ & 73.13 & Sufficient \\
\hline
\end{tabular}

Institutions

Move from

Linear Economy

Waste

Management to

0.798

Positive

The Circular

Economy

\begin{tabular}{|c|c|c|c|c|}
\hline Indicator & $\begin{array}{c}\text { Correlati } \\
\text { on }\end{array}$ & Result & Score & Categori \\
\hline $\begin{array}{l}\text { Local Cost } \\
\text { Recovery - } \\
\text { From } \\
\text { Households }\end{array}$ & 0.481 & $\begin{array}{c}\text { Positive } \\
\text { Correlatio } \\
n\end{array}$ & 76.13 & Sufficient \\
\hline $\begin{array}{l}\text { Degree of Clean } \\
\text { Technology } \\
\text { Used }\end{array}$ & 0.769 & $\begin{array}{c}\text { Positive } \\
\text { Correlatio } \\
\mathrm{n}\end{array}$ & 70.57 & Not good \\
\hline $\begin{array}{l}\text { Suitable } \\
\text { Infrastructure }\end{array}$ & 0.649 & $\begin{array}{c}\text { Positive } \\
\text { Correlatio } \\
n\end{array}$ & 68.50 & Not good \\
\hline $\begin{array}{l}\text { Develop and } \\
\text { Keep Improving } \\
\text { A Waste } \\
\text { Information } \\
\text { System }\end{array}$ & 0.647 & $\begin{array}{c}\text { Positive } \\
\text { Correlatio } \\
\mathrm{n}\end{array}$ & 72.27 & Sufficient \\
\hline $\begin{array}{l}\text { Number of } \\
\text { Disposal Sites } \\
\text { Complying With } \\
\text { Defined } \\
\text { Operation } \\
\text { Standards }\end{array}$ & 0.627 & $\begin{array}{c}\text { Positive } \\
\text { Correlatio } \\
n\end{array}$ & 67.17 & Not good \\
\hline $\begin{array}{l}\text { Degree of } \\
\text { Communication } \\
\text { and } \\
\text { Collaboration for } \\
\text { Recycling } \\
\text { Programme }\end{array}$ & 0.644 & $\begin{array}{c}\text { Positive } \\
\text { Correlatio } \\
n\end{array}$ & 73.10 & Sufficient \\
\hline $\begin{array}{l}\text { Degree of } \\
\text { Performance } \\
\text { Monitoring }\end{array}$ & 0.797 & $\begin{array}{c}\text { Positive } \\
\text { Correlatio } \\
\mathrm{n}\end{array}$ & 71.57 & Sufficient \\
\hline $\begin{array}{l}\text { Effectiveness in } \\
\text { Achieving } \\
\text { Behavior } \\
\text { Change } \\
\end{array}$ & 0.824 & $\begin{array}{c}\text { Positive } \\
\text { Correlatio } \\
n\end{array}$ & 73.63 & Sufficient \\
\hline $\begin{array}{l}\text { Stakeholder } \\
\text { Participation }\end{array}$ & 0.782 & $\begin{array}{c}\text { Positive } \\
\text { Correlatio } \\
n\end{array}$ & 74.63 & Sufficient \\
\hline $\begin{array}{l}\text { Public Education } \\
\& \text { Awareness }\end{array}$ & 0.761 & $\begin{array}{c}\text { Positive } \\
\text { Correlatio } \\
n\end{array}$ & 75.57 & Sufficient \\
\hline $\begin{array}{l}\text { Institutional } \\
\text { Arrangements }\end{array}$ & 0.920 & $\begin{array}{c}\text { Positive } \\
\text { Correlatio } \\
n\end{array}$ & 77.60 & Sufficient \\
\hline $\begin{array}{l}\text { Endorsed } \\
\text { National Waste } \\
\text { Strategies }\end{array}$ & 0.925 & $\begin{array}{c}\text { Positive } \\
\text { Correlatio } \\
n\end{array}$ & 74.07 & Sufficient \\
\hline
\end{tabular}

Based on the results of the above assessment, it is known that all indicators have a positive correlation with the variables, and each variable is positively correlated to measure green waste in the city of Bandung. From the results above it is also known that the lowest score of the indicator in measuring green waste is source separation of dry recyclables with a score of 65.90 which is included in the unfavorable category, and the highest score is an indicator of institutional arrangements with a score of 77.60 which falls into the sufficient category

\section{Proposed Green Waste Measurement Model}

From the results of qualitative analysis, based on answers to the results of interviews with resource persons, the results obtained as much as $12 \%$ of resource persons stated agreed to the indicators unit cost of recycling operation is an indicator in measuring financial sustainability. Based 
on these results the author decides not to use these indicators in the proposed model to be presented.

While based on the results of quantitative calculations using the Spearman Rank correlation through the IBM SPSS Statistics 21 software, the results show that of the 5 variables and 21 indicators tested all have a positive correlation value. Therefore, the results of the analysis are qualitative and quantitative, The variables and indicators used to measure green waste in Bandung are as follows:

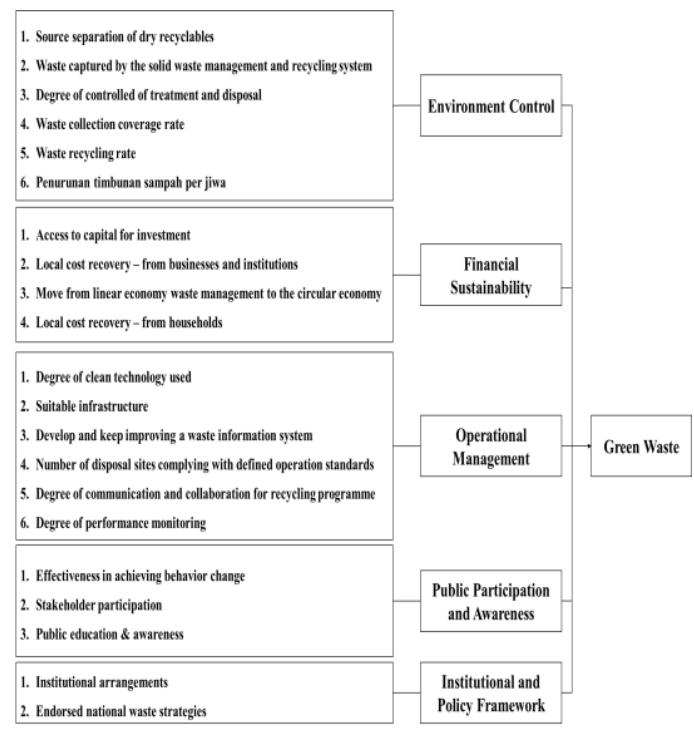

Figure 2

Proposed Green Waste Model

\section{Green Waste Index in Bandung City}

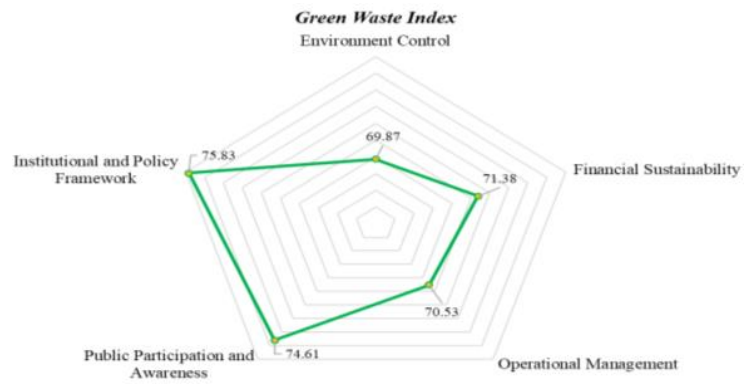

Based on the results of calculations and analysis shows that the green waste index in the city of Bandung is in the Fair category with a score of 72.44. The highest number is in the institutional and policy framework variable with a score of 75.83 , while the lowest number is in the environment control variable with a score of 69.87 .

\section{CONCLUSION}

Based on the results of research on the measurement of the green waste index in the city of Bandung. Can be concluded as follows:

1. The results of interviews conducted with 30 resource persons, found that the variables and indicators that can be used to measure Green Waste in the city of Bandung is to use 5 variables and 21 indicators in accordance with the proposed model that has been presented.

2. Based on qualitative results, the unit cost of recycling operation indicator in the financial sustainability variable has a value of $12 \%$. Therefore, the development of a model to measure Green Waste in the city of Bandung is not to include these indicators, according to the proposed model that has been presented.

3. The Green Waste Index in Bandung City has a value of 72.44 which is included in the sufficient category, where currently the application of green waste based on 5 variables measured is considered sufficient.

\section{Suggestions \\ Practitioners suggestions}

Based on the results of the interview, the resource person considered that the Government was still less assertive in implementing sustainable waste management policies. On the other hand, the lack of public awareness of sustainable waste management and businesses in producing sustainable products results in an index of green waste implementation in the city of Bandung is still in the sufficient category. Therefore it is important for collaboration between stakeholders from stakeholders, business actors, and the community to be able to change behavior in waste management in terms of both business sustainability and urban survival.

\section{Academic Advice}

Researchers do not make comparisons of the application of green waste in other countries or based on good practice when conducting interviews with resource persons. it is expected that in subsequent studies it can make a comparison of the application of green waste based on good practice and application in other countries, other than that in this study, researchers did not weight the indicators and variables in the measurement of the green waste index. it is expected that in subsequent studies we can weight the indicators and variables in measuring green waste.

\section{REFERENCE}

Bapeda aceh. (2019). program strategis green city. Retrieved from https://bappeda.bandaacehkota.go.id/programstrategis/green-city

BKPRN. (2012). Gerakan kota hijau. Buletin Tata Ruang.

Boztepe, Aysel. (2012). Green Marketing and Its Impact on Consumer Buying Behavior. European Journal of Economic and Political 
BPS Bandung. (2019). Proyeksi Penduduk dan Laju Pertumbuhan Penduduk di Kota Bandung, 2012 - 2017. Retrieved from https://bandungkota.bps.go.id/statictable/2019/ 01/04/181/proyeksi-penduduk-dan-lajupertumbuhan-penduduk-di-kota-bandung2012---2017.html

BPSKotaBandung. (2020). Badan Pusat Statistik Kota Bandung. Bandungkota.Bps.Go.ld, pp. 1-346. Retrieved from https://bandungkota.bps.go.id/news/2020/01/0 7/15/sensus-penduduk-2020--sensus-eradigital---.html

Buku Panduan Penyelenggaraan P2KH 2017 - Kota Hijau. (n.d.).

BKPRN. (2012). Gerakan kota hijau. Buletin Tata Ruang.

Creswell, John W., \& Creswell, J. David. (2017). Research design: Qualitative, quantitative, and mixed methods approaches. Sage publications.

dan Sunarto, Riduwan. (2007). Pengantar Statistika. Untuk Penelitian Pendidikan, Sosial, Ekonomi,
Global Waste Management Outlook. (2016). In Global Waste Management Outlook. https://doi.org/10.18356/765baec0-en

Indrawati, Ph D. (2015). Metode Penelitian Manajemen dan Bisnis Konvergensi Teknologi Komunikasi dan Informasi. Bandung: PT Refika Aditama.

Nagaraju, B., \& Thejaswini, H. D. (2014). Consumers' perception analysis-Market Awareness Towards Eco-Friendly FMCG products-A case study of Mysore District. IOSR Journal of Business and Management, 16(4), 64-71.

Sujoko, Anang, Safitri, R., \& Anindita, Ratya. (2007). Pemanfaatan Multimedia dalam Pembelajaran sebagai Alternatif Optimalisasi Keseimbangan Kerja Otak kiri dan Kanan Guna Meningkatkan Kualitas dan Daya Saing Lulusan. Prosiding Abstrak. Disajikan Dalam Simposium Nasional.

Yazdanifard, R., \& Mercy, Igbazua Erdoo. (2011). The impact of Green Marketing on Customer satisfaction and Envi- ronmental safety. 

